American Journal of Applied Sciences 3 (9): 1999-2004, 2006

ISSN 1546-9239

(c) 2006 Science Publications

\title{
Role of the Electronic Banking Services on the Profits of Jordanian Banks
}

\author{
Ahmad Zakaria Siam \\ Al Balqa Applied University \\ Amman College for Administrative and Financial Sciences, Jordan
}

\begin{abstract}
This study aims at examining the effects of electronic banking on bank's profitability in Jordan. How banking sector finds itself before a new fact imposed by technology revolution and digits to change their work mechanisms from traditional means to electronic means and the challenges banks face as a result. Furthermore, this study investigates the reasons behinds providing electronic banking services through internet, their impact on banking services in general and banks profitability in particular. Risks and challenges involved are discussed Results and recommendations are included. Results revealed that electronic banking service has a negative effect on banks profitability on the short term. The importance of this study and the factors that make it unique is that, it discusses solely the topic of the effects of electronic banking on banks profitability, while most of other studies discuss the topic in general term. The findings of the study are the impact of electronic banking on banks profitability will be feature of the short run due to the capital investment by the banks on infrastructure and training but will be positive on the long run.
\end{abstract}

Keywords: Internet, electronic banking, profitability.

\section{INTRODUCTION}

The world witnesses an information and technological revolution. This revolution has touched every aspect of people's life including banking. Such changes and development have impacts on services quality, future of banking activities, and consequently, it's continually competition ability in the world markets since going along with technology is one of the most important factors of economic organizations success in general and banks in particular. This motivates banks to spend more on technology and information to achieve maximum returns and attracting large number of clients. Furthermore banks have to provide an excellent service to customers who are sophisticated and will not accept less than above average service. Thus, the issue of service marketing in general, and banking services in particular has become one of the most important and modern directions which have witnessed a substantial expansion during the last years in almost all societies. This is because the increasingly significant role which banking services have with the widening and variety that these services are characterized with, thus banking services have touched most aspects of contemporary societies life and activities.

Researcher has found that previous studies have not given the subject of (effects of electronic banking on banks profitability) its complete far share. Thus, researcher started this study to fill this gap and have the study complementing previous studies in this field.
In addition, the emergence of newer banking services which are completely differs from the traditional services that people accustomed to, prompts people and organizations in Jordan to increase their banking activities. However, there still many factors that influence the customer's visualization and impression in regard to the type of banking services they will receive; consequently these external and internal factors make the customer's purchasing decision harder and more complicated, and because the increasing importance of service sector, scarcity of published research about the new or the electronic banking services, and its effect on the cost, time and profitability of the bank, this study has come along to discuss the effects of the electronic banking services on the bank's profitability. It is expected and hoped that the findings of this study would contribute to know the effects of the electronic banking services on the bank's profitability and the other relevant issues.

Study's objectives: Besides the study's aim which is the revealing of the effects of electronic banking services on bank's profitability, this study has few objectives that can be summarized as follow:

- The impact of changes from traditional banking services into electronic ones, on banks as well as on customers, banks measures to cut costs of their electronic operations, and the future of electronic banking in Jordan. Therefore this study attempts to answer the main following questions. 
- What are the electronic business and internet, what is the main motive for banks to turn towards providing electronic banking services, and does it face difficulties and barriers for this sake?

- Is the prevailing framework of electronic transactions sufficient to protect working banks information systems and consequently does there banks have the required electronic software and human competence to keep up with digital world and achieve the banking distinction?

- To realize the practical fact of providing banking services through banks web sites, and consequently does the client is educated and the employee is trained on electronic dealing, do the current rendered services level is sufficient to meet competitive purposes and to achieve the quality of banking service?

Study's importance: The importance of this study stems from the following items:

1- The size of service sector and its importance in economy: The size of service sector and its contribution to most of world's economies is in rapid increase. Whereas the service sector contributed in 2005 by $74 \%$ of the working force in the USA and $67 \%$ in Canada. However in regard to Jordan which its economy is service economy in the first place; the rate of service sector contribution to the working force is $72 \%{ }^{[1]}$.

2- Field research scarcity in this field: There are very few studies about the electronic banking services impact on banks profitability. At the same time this topic hasn't received the sufficient research and study by people involved, while electronic banking services in growing constantly in Jordan as well as the rest of the world ${ }^{[2]}$.

What makes this study different from other studies? This study does not differ greatly from other studies in this field; however it differs in some matters which make it a distinct study such as:

This study reveals the most important obstacles which stand on the way of providing electronic banking services by the Jordanian banks. Where as to researcher's best knowledge- there is no single study discusses these obstacles as a separate topic by itself, other studies discuss the advantages, characteristics and the benefits which the Jordanian bank obtain from their electronic services such as the study by ${ }^{[3]}$.

This study is a distinguished one because it reveals the major reasons for the banks to use internet to provide services to their customers, and the factors which lead to the success of the operations (more profits) and the ability to manage risks of using electronic means by bank's management.

Finally, this study is a unique one because it discusses the effects of electronic banking services on bank's profitability.

Unfortunately the electronic banks in Jordan has not received the proper attention by researchers, according to the university of Jordan's information center (belongs to the library), despite the fact that there are many banks which provide such services.

The following are samples of international and local previous studies in this regard:

1- The research paper ${ }^{[3]}$ aimed to examine the current and potential characteristics of electronic banks, and the earned benefits from internet use to produce, provide and market banking services, along with electronic technology in banking industry with the focus on the strategic roles of electronic banks and analyze Jordan as a case study in this field. They interviewed 98 managers at 17 banks $^{\text {[4] }}$.

In fact, the use of electronic communication in finance goes back much further than the 1970s. As long ago as 1918, the payments between banks used to be settled electronically over the telegraph. This use of electronic communications in payments systems has steadily increased over time. Now virtually all large payments between banks and corporations are done electronically. Financial services industry has removed the boundaries between different financial institutions, enabling new financial products and services to appear and making the existing ones available in different packages.

According to ${ }^{[5]}$, electronic banking refers to the use of the Internet as a remote delivery channel for providing services, such as opening a deposit account, transferring funds among different accounts and electronic bill presentment and payment. This can be offered in two main ways. First, an existing bank with physical offices can establish a Website and offer these services to its customers in addition to its traditional delivery channels. Second, is to establish a virtual bank, where the computer server is housed in an office that serves as the legal address of such a bank. Virtual banks offer their customers the ability to make deposits and withdraw funds via ATMs (Automated Teller Machines) or other remote delivery channels owned by other institutions, for which a service fee is incurred.

The study ${ }^{[6]}$ indicated that, Electronic Funds Transfer (EFT) was introduced in the late 1970s. ATM, telephone banking and the acceptance and growth of credit cards were introduced in the 1980s. According to [7], it costs just two cents for an Internet transaction, compared with 36 for an ATM transaction and \$ 1.15 for a teller-assisted service. Despite that, consumers have still given their orders to transfer money in 
traditional ways. The main reasoning for that, according to ${ }^{[8]}$, is that since no Internet security firewall can be guaranteed perfect, both sellers and buyers may be concerned that competitors will be able to extract sensitive or proprietary information, or a virus might spread from one participant in the exchange to others.

According to ${ }^{[9]}$, consumers are demanding and expecting more than just one set of banking products from their forays online and off-line.

[10] Stated that, banks are using the Internet as a strategic weapon, leveraging it as a distribution channel to offer complex products at the same quality they can provide from their physical branches, at a lower cost, to more potential customers, without boundaries. [11] Proposed that, banks can become technology providers by spinning off technology resources to start up new business streams, they can become content providers for information regarding products, indices etc, they can become context providers for setting-up e-market spaces, and also enablers by providing back bone systems to support multiple payment system alternatives.

According to ${ }^{[12]}$, the online channel enables banks to offer low-cost, high value-added financial services and also benefit from the promotional opportunity to crosssell products such as credit cards and loans.

${ }^{[13]}$ Indicated in his study that, online transaction costs can be as low as $1 \%$ of an equivalent off-line transaction, rapidly increasing the popularity of the online option with consumers, as well as banks. In saving time and money for users, banks offer online banking as a less expensive alternative to branch banking. In addition, on-line banking enables banks to acquire information on consumer habits and preferences, for later marketing purposes. An expanding customer base and transaction cost savings are major benefits for banks.

The most important findings of their study are: 1) the study samples of banks have showed that they completed the technological infrastructure for electronic banking services, internet and intranet in particular and the development of banks web sites. 2) People prefer to provide electronic banking services through the internet but not converting the bank to be a total electronic bank. 3) The environment is no completely ready for electronic banking services and there is no strategy to have electronic banks on the internet.

There is another study by Shuqair 2003 entitled "Practical electronic banking services by the Jordanian Banks" one of the most important finding in this study is that; the high cost of electronic banking services on the short run due to the training of employees, and the costs of the electronic infrastructure. This means, that in the short run electronic banking service will have a negative effect on the bank's profitability.

Finally these studies and other coming studies need to address the effects of electronic banking services on bank's profitability. Some studies showed that people (customers) prefer electronic banking services over the traditional ones ${ }^{[14]}$.

The study is based on discussing and proofing the validity of the following hypothesis:

1. Electronic Banking services have a positive effect on banks profitability.

2. There is a direct relation between increment of clients needs for banking services and bank's distinction in providing electronic business.

3. The operation of providing electronic banking services is influenced by bank readiness and availability of electronic software and qualified man power.

4. Confidentiality and privacy have clear impact on protecting clients and bank from risks, and consequently the framework has an impact on banks information systems and its management upon providing banking services though Internet.

Study population is consisted of all working banks in Jordan which have sites on internet regardless its activate dealing with electronic banking business or not, the study samples included all banks mentioned in annex No (2), taking in consideration the time differences of these banks joining electronic service world, and its interest to develop its electronic work to provide the distinguished executive services to customers. The study sample consists of 20 commercial Banks operating in Jordan.

At the beginning of the 1980s NSF NET Company was established aiming to link the giant computers of high speed for scientific purposes. This net replaced ARPA NET and NSF NET became the basic pillar in Internet world ${ }^{[14]}$.

\section{RESULTS}

For the purpose of identifying the implementation extent of electronic banking services in the banks "study sample" we have distributed the following questionnaire, which consists of twenty questions. The responses categories were divided to determine its frequencies to "Always- sometimesrarely". All answers were treated with full confidentiality, knowing that the questionnaire was distributed over the twenty working banks in Jordan. The responding percent was $100 \%$, in spite of the fact that some banks does not deal with executive services up to now. 
The responses have indicated that number of browsers of banks sites on Internet still below the required level. But Internet widespread has deepening the concept of electronic business and considering it as promotion, bank service marketing method and successful method to improve banks relation with clients, informing them with available banking abilities through Internet in spite of small size of Internet community in Jordan, which is used mostly by youth group who have high income or more than the middle approximately, which will reduce the importance of Internet and number of users.

In addition to short age of Internet banking services which were emerged in 2000 in Arab Bank and City Bank. This reflects importance of site activating through the net, since it is not sufficient for the bank to have a site on the Internet only. But the need is to activate the site and provide banking service through. In spite of some banks have the desire to provide banking services through Internet, but its study is not yet completed, and they are working to achieve that regardless of their fear of banking deception.

It was clear to us from the responses that majority of bank dealers through Internet are those whom their income is high. Furthermore most of Internet dealers are from youth category. We were also assured of banks desire to deal with internet banking to go along with technology and new digital world for the purpose of competition and quality achievement in the provided services and enhancing competition, by the evidence of attracting more new clients upon introducing the internet in banking business as a result to save time, money and effort.

The responses confirmed that bank site on Internet has great effect in achieving bank goals which enhances bank investment of its site to deliver its banking services.

Among the most important services provided by banks are: balance inquiry, account statement demand, checks book, and transferring from one account to another. But other services such as selling and purchasing real estate, cars funding and payment of phone bills does not get high percent of bank and clients interest. It was clear to us that majority of banks are working to provide Home bank, mobile, ATM, and Visa card, seeking for achieving automatic bank which provide services with no need for persons.

Although the questionnaire has shown the bank desire to deal with Internet to achieve competition position to go along with globalization and digital world age, but the executive services still below the required level in terms of accounts opening and running, dealing with documentary credits, collection polices, stocks investment and warranties settlement. In spite of unanimity of study sample majority regarding availability of human power and the required electronic software to provide such services, but the belief of some of them that legal framework for electronic transactions is not enough has caused limitation of providing such services.

The majority of banks in Jordan which have electronic sites for introducing services and branches agreed on the confidently and privacy necessity in electronic banking business. This was mentioned in study literature review. Those banks agreed on providing electronic banking services will enhance bank competition and performance, which will enhance attracting new clients and increasing bank's clients belonging that maximize profits and reduce operation costs as a result of increasing bank's business.

The main motive for providing services through Internet is to go along with the advancement of digital world and to achieve distinction, and making electronic executive services available for clients without direct dealing, since infrastructure and electronic software are available in most banks besides the skilled human power.

Any one who examines carefully the questionnaire will find the clear impact of client's need and demands on distinctive level of electronic banking services, since one of the reasons for providing banking service is new client's needs and bank's need for client's loyalty, which enhances bank's management to receive client's suggestion and meeting their desires. Furthermore, electronic services contribute in reducing costs, increasing profits, activating bank's management, increasing bank's effectiveness and its competitive degree. This reflects the direct relation between increasing client's needs to reduce time, costs and between electronic banking services.

The study also reflects the existence of clear direct relation between management efficiency and organizing and between providing electronic services, this means that the more increase of management interest to follow up, updating the site, adding every new to the provided services through the net and its acceptance of client's suggestions regarding services improvement, the more increase of direct relation between that and between distinctive electronic banking services, profits increased, costs reduced and quality achieved.

\section{DISCUSSION}

This study is conducted on a sample of 20 Jordanian Banks, for the purpose of examining the effects of electronic banking services on banks 
profitability in Jordan, along with other relevant information.

Researcher has difficulty in locating previous studies which discuss solely the impact of electronic banking services on banks profitability.

Even though, there are very few studies about the topic which gives general insight to the electronic banking in Jordan. Despite all of these difficulties the study has revealed some important findings such as:

First: The effect of electronic banking services on banks profitability is negative in the short run. This is because of the costs and the investments the bank carry to have the technical and electronic infrastructure; train their employees to be skilled and competent in theis field and prepare what is called an electronic environment where the banks can electronically operate smoothly.

Second: Banks could suffer slight financial difficulties such as short of revenues from its electronic services because the Jordanian people in general don't use the internet as it suppose to be. Most of them prefer walking to the bank and chat with employees while conducting business especially in banks out of the greater Amman area. However corporation, business people and university students prefer dealing with a bank which provides electronic banking services, over the bank which doesn't.

Third: Most banks will benefit greatly from providing electronic services on the long run; because the technology is here to stay and is not a trend, it is matter of time.

Finally, results from data analysis that were gathered from the study`s instrucment (questronnaire) show the following facts:

a. There are a correlation with statistical significance between the impact of electronic banking in banks profitability as the following:

1. a negature effect in profitability in the short run.

2. a positive effect on profitability on the long run.

b. Alangers and banks employees prefer their banks to expand their electronic operations in servicing customers, but not converting bank into a total electronic banks.

c. Electronic banking services in Hordan still at its early stages. However, it is reality and not a trend, especrally Jordan as people, institutions in both private and public sectors are gearing up their efforts towards the maximun use of the internet and IT.

\section{CONCLUSIONS}

1- $\quad$ The majority of banks (sample study) have electronic sites on Internet since more than two years, such Arab Bank, Jordan Kuwaitis Bank, and City Bank, which their electronic business started on 2000. Some banks are seeking to have site in order to provide executive services.

2- With respect to client's number and type who are using Internet, the majority is of high income and the number is increased successively due to the increase use of Internet in our day life.

3- Most of banks still provide traditional electronic services such as ATM, and Visa card, whereas Internet still not used for electronic executive business by the banks. This breakdown qualified human abilities and available electronic software.

4- Banks complain from inefficiency of framework which protects banks information systems confidentiality. Banks believe that the current electronic business law is not sufficient as comprehensive legal framework includes electronic business in banking and financial institutions.

5- Among the findings which draw the attention is the increased need to electronic banking services due to new client's needs, bank expansion in providing electronic services increases number of clients and enhances their loyalty to the bank which reduce the operational costs by increasing banking transactions through Internet, so bank's outcomes will be increased and also profits increased by reducing time and effort, and achievement of electronic banking service quality.

6- Banks management interest in site on Internet was shown for introduction the available services and inventing the nonavailable ones, by listening to client's suggestions and comments, site updating, exploiting Internet as promotional and marketing bank media.

\section{RECOMMENDATIONS}

This complementary study recommends that the supporting of banks to expand their electronic services in a planned and well articulated stratgy for the long run, in order to have customer satisfaction and increase in banks profitability. 
Due to non-perfect understanding of electronic banking applications, we recommend increasing and propagating awareness of internet banking. Consequently the banks are requested to carry out awareness and promotion campaigns to educate clients and aware them of Internet banking dealing advantages and feasibility through reducing time, effort and reducing cost for achieving distinctive and competition position.

2- $\quad$ To expand electronic bank establishing to widen dealers base and to enhance banks ability in providing executive banking services under the phenomena of banking merge and comprehensive banks.

3- $\quad$ To hold training courses for bank's employees to understand electronic banking business to achieve the desired objectives. Universities and academic institutions are requested to link higher education with market needs of skilled and professional man power having the ability to deal with electronic software under the challenges. We confirm the necessity of teaching courses that have direct relation with digital world, electronic software in electronic business field in banking and financial institutions.

\section{REFERENCES}

1. National Information Center and the Central Bank publications 2004

2. 2.www.css-jordan.org/arabic/economic/workshop.

3. Refa'I, Ghaleb Awad, and Yaseen Saed Ghaleb, 2002. Electronic works in Banks. Al Zeytuneh Magazine for Studies, Scientific Research, and Humanities, vol. 1, No. 2, pp: 71-94.

4. www.jordan.jo

5. Zairi, A., 2003. Global Benchmarking for Internet and E-Commerce Applications. Proceedings of the First International Conference on Performance Measure, Benchmarking and Best Practices in New Economy, Business Excellence, University of Minho Guimaraes, Portugal.

6. Distr, 2003. Development of E-Commerce Sectors in the Arab Region. Proceedings of the Western Asia Preparatory Conference for the World Summit on the Information Society (WSIS), Beirut.

7. Moon, Y and Fre, F, 2000. Exploding the Selfservice Myth. Harvard Business Review, 78-3, pp: 26-27.
8. Doyle, T. and Melanson, J., 2001. B2B Web Exchanges: Easier Hyped Than Done. Journal of Business Strategy, 22-3, pp: 10-13.

9. Dial, T., 1995. Differentiate Strategies for Future Success. Bank Management, 71, No. 5, pp: 20-22.

10. Stamoulis, D, 2000. How Banks Fit in an Internet Commerce Business Activities Model. Journal of Internet Banking and Commerce, Vol. 5, No. 1.

11. Fan, M., 2002. Electronic Commerce and the Revolution in Financial Markets. Thomson Learning, USA, pp: 223-238.

12. Hawkins, J, 2001. The Banking Industry in the Emerging Market Economies: Competition, Consolidation and Systemic Stability: An Overview. BIS Papers No. 4, pp: 1-44.

13. Turban, E. 2002. Electronic Commerce a Managerial Perspective. Prentice Hall, U.S.A, p. 179.

14. www.EBSCO.com.

15. Zairi, A and Alwabel, S., 2005. The Web and it's Impact on the Provision of Financial Services: A Benchmarking Perspective of Saudi Banks. Bradford University School of Management, Working Paper No 05/18, pp: 58.

16. Ronald Ashri and others, 2001. Professional Java E-Commerce, Wrox press Itd, Bermingham, UK.

17. Deitel, P.J and Dertel, T.R. Nieto, 2001. EBusiness and Commerce- How to program, prentice Hall.

18. Donal O’Mahong, Michael pierce, 2001. Electronic payment systems for E-commerce, Artech house, $2^{\text {nd }}$ edition.

19. SCN Education B.V. (Eds), 2001. Electronic Baninkg: The Ultimate Guide to online Banking, Friedrickvieweg \& Sons.

20. Ezra Zask, 2001. The E-Finance Report, McGraw-Hill Trade.

21. Micheal Peirce, 2001. Electronic payment systems for E-commerce, Artech house.

22. Brain Nixon and Mary Dixon, 2000. Sams Teach yourself e-banking today, Sams.

23. Erik Banks, 2001. E- Finance: The electronic revolution, John Wileg \& Sons.

24. www.alrai.com

25. www.researchandmarkets.com. 